\title{
SOME THOUGHTS ON RF ENERGY HARVESTING
}

\author{
Sergey G. Bunin, Roman Yu. Zhohov \\ Institute of telecommunication systems, NTUU “Kiev Polytechnic Institute”, Kiev, Ukraine
}

Background. Energy harvesting is the actual topic. The system for energy harvesting has many components which require complex designing.

Objective. The aim of the paper is optimal ways of collecting and accumulation of electromagnetic energy.

Methods. Analysis of all known publications devoted to the energy harvesting, and induction of optimal elements for the energy harvester.

Results. Optimal solutions and some practical implementations were proposed for each element of the energy harvester. Moreover, IR-UWB signals were proposed as a candidate for energy effective communications.

Conclusion. Energy harvesting can be effectively used for power supply for some devices (for instance, sensors). Also, energy effective communications (for instance, IR-UWB) can be used in those devices.

Key words: energy harvesting; UWB; sensors; supercapacitors.

\section{Introduction}

Cellular networks have become the basis of the global mobile communications. The vast majority of the world's population has mobile phones, the number of phones exceeds 2.6 billion units [1]. In the near future we expect the number of "gadgets" (- ultra-miniature sensors and control devices) to grow rapidly. We are talking about the concept of the «Internet of Things». For instance, there are "smart" environments, which based on WSN; different automation systems, which are combined into a single network of various types of sensors. The sensors do the supervision of the state of devices and systems, and control their parameters. Also, different types of D2D communications can be contribute to the concept of WSN and "Internet of things" [2]. Moreover, we can define the whole group of devices, which called - Health Wearables, they include fitness bands, jewelry, smart watches, clothes, sunglasses, and a variety of other devices "in and around the body", with built-in sensors and other electronic technologies for controlling the parameters of the body[3].

The recent trends that were mentioned in works [4], [5] develop the concept of "smart dust" (the myriad of tiny devices which have a size up to the microscopic sensors and robots, that will collect the information in different devices, objects and environments, transmit it to the processing centers and perform the control on objects). The need for development this kind of ultra-miniature electronics is beyond doubt. There are a lot of applications where these devices can be used: medicine (where constant monitoring of body parameters is very important), ecology, agriculture, industry and military applications (to monitor and change the situation in operations), etc.
It's important to notice that current research activities are also concentrated on the recent trend, which can be called "Internet of No Things", we are talking about the "Naked Approach" project [6]. The main idea of this project is to change "gadget-oriented" approach to smart environments and "person-oriented" way of deploying and using electronics. These changes can be implemented because of the following factors:

1. Increase in accessible information;

2. Increase in the role of APIs;

3. Growth and abundance of computing power;

4. Miniaturization;

5. Sensors;

6. Energy self-reliance;

7. Stick-it-on devices;

8. Printable electronics;

9. Digital surroundings;

Despite the success of the miniaturization of electronics, one of the main problems of the practical implementation is the power supply. Due to disunity of sensors and difficulties in connection to the power lines, the chemical sources such as batteries are usually used. We talk about the small batteries that are used in watches, small computers in stand-by mode, etc. The need of the regular replacement "costs a bomb" and it's very inconvenient to charge the batteries. On the other hand, when the size of a sensor is commensurated to the battery size or even less, in this case the problem of power supply is a decisive reason. Downsizing a battery means reducing its electric capacity, hence increasing the frequency of battery's recharging or replacing. The problem is compounded, when sensors are installed in specific environments, such as on factory's pipes. Thus, 
different solutions for the sensor's power supply are needed.

\section{Energy around us}

We live in the world which is full of electromagnetic energy. The sun radiates energy in a wide frequency range - from thermal and visible to ultraviolet radiation. The direct conversion of electromagnetic radiation from the sun into electric current for low-power devices (watches, calculators, etc.) by small solar panels has long been widely used. However, the sun shines, on average, half of the time of day, the duration of which in the polar regions reaches half of the year. So if we want to use these devices at night or in the darkness, then again, the same need to have sufficient battery capacity. Yes, the sun or the man-made light, of course, are the best sources of energy ... if they are available. In other cases, we need to find other natural sources of energy, which will be applicable for a power supply of a huge amount of micro- devices. For instance, in areas where thunderstorms are frequent, we can charge the batteries or other electrical accumulators from storms and static electricity, which is usually presented during thunderstorm activity.

Man-made Electromagnetic Energy Sources

In addition to natural sunlight, living space filled with electromagnetic fields generated by man-made devices - radio transmitters of different systems: broadcasting, communications and radars. The most powerful sources among them are:

- TV broadcasting transmitters;

- Radio broadcasting transmitters (VHF and AM bands);

- Base stations of cellular communications (GSM, 3G, 4G);

- Airport surveillance radars;

- Due to abundance of access points (Hotspots) of networks which are based on IEEE $802.11 \mathrm{a} / \mathrm{b} / \mathrm{g} / \mathrm{n}$ (Wi-Fi), it was proposed to feed small devices from power transmitters of access points (socalled Power of Wi-Fi - (PoWi-Fi). Recent articles on this subject can be found in [10].

The level of power from these transmitters is the highest where the large number of them is available, namely in cities, i.e. just in the areas where the number of sensors will be the largest. The interesting fact is that to $99.9 \%$ of the radiated power of these transmitters is wasted. We must specify the equivalent isotropic radiated power (EIRP) of the transmitter is intended only to satisfy the desired signal-to-noise ratio in the zones, to be exact, at the reception points. In the rest of the space, the radiated energy warms the atmosphere, the earth, plants, people and animals, which is obviously not the desired effect. Paradoxically, but if the subscriber doesn't listen to the program or doesn't watch it, we can assume that the energy that was intended for subscriber's receiver is wasted too. The question arises: "Is it possible to use the "free" electromagnetic energy sources to power electronic "gadgets"?". This idea has been used for several years and it's called «Energy Harvesting», also works on practical application are widely studied in many countries [7], [8], [9].

It is obvious that the decision on the energy harvesting for power supply in each case depends on ratio of the amount of energy that can be collected from the air at the location of powered devices to the average energy consumption for the device $\left(E_{\text {out }}\right)$ at the same time. If the ratio is greater than 1 or equal to 1 , it is advisable and possible to power the device:

$$
E_{\text {in }} / E_{\text {out }} \geq 1
$$

We note that the number of powered devices in these areas is almost unlimited if we don't have any absorbing or shielding barriers between the source and the consumer of energy. We call the device having the ratio is greater than 1 Electromagnetic Powered Devices (EPD).

Finally, in places where the power level is insufficient for the EPD, specifically designed transmitters can be used to power devices in the surrounding area. In [11], [12] authors proposed to use RFID technology for Energy Harvesting.

Practically, power levels can be determined using spectrum analyzer by estimating the total power at the point of reception. For example, Fig.1 shows a screen shot of the spectrum analyzer connected to the 10-centimeter rod antenna, located on the 5th floor of a six-storey concrete building in Kiev, located about 4 kilometers from the 300-meter tower, on which there are antennas for more than two dozen television transmitters (VHF, UHF) and one dozen FM (VHF) broadcasting transmitters.

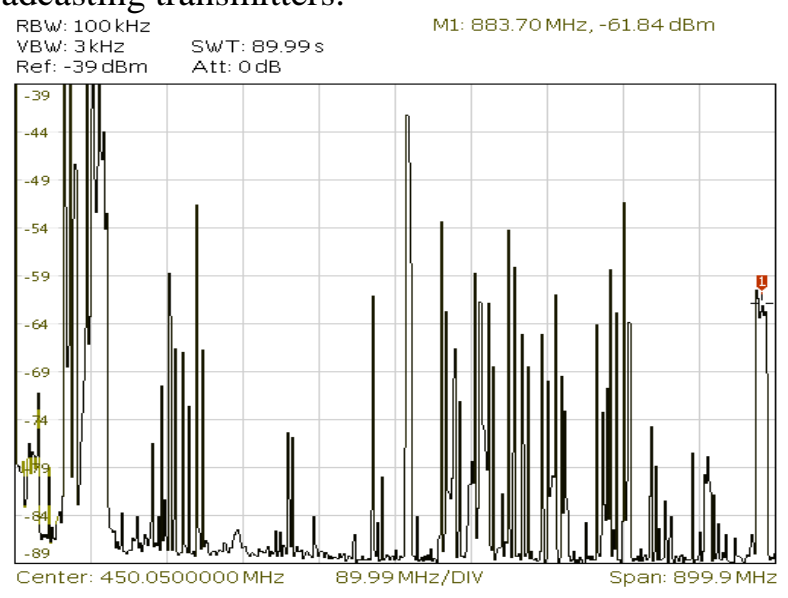

Fig.1. Spectrum (100 kHz to $900 \mathrm{MHz}$ ). 
In addition, at a distance of $200 \mathrm{~m}$ there is a base station of a cellular mobile GSM network (900 MHz band (marked 1 on Fig.1)). Summing a total power from all the sources (by integrating the area under the spectral curve) we received power value at the point of reception about $2 \mathrm{~mW}$ (using non-optimal antenna). Approximately, the same level of power was available in the whole building and surrounding space. Consequently, such a power level would be enough for a large number of devices.

\section{Energy Harvesting Device Structure}

Generally speaking, the problem of Energy Harvesting can be divided into following components:

- "Catching" electromagnetic energy from the space (which can be implemented by an antenna) and converting it into electric current;

- Converting the received energy to a predetermined voltage value;

- Accumulation of energy in any storage element or charging the device;

\section{Antenna}

The power level of each point in space can be represented as the sum of the power fluxes $P$ (EIRP) from all the available i sources located at distances ri from the reception point, multiplied by the effective aperture of the receiving antenna $A_{i}$ (for the particular wavelength) and the path loss $\gamma_{i} \leq 1$ :

$$
P=\sum\left(\frac{\gamma_{i} P_{i}}{4 \pi r_{i}^{2}} A_{i}\right)
$$

As we can see, received power level depends on the sum of EIRP of transmitters, distances and effective apertures for these waves. The effective antenna aperture $\mathrm{A}$ is the ratio of the power $(\mathrm{P})$ received on its load to the power flux density (W) of the received wave at reception point:

$$
A=\frac{P}{W}
$$

The effective aperture depends on the ratio of the wavelength $\lambda$ and geometrical dimensions of the antenna (the length of the wire antenna elements, the values of the spatial aperture antennas), form of the antenna elements, their relative orientation and mutual polarization.

Due to the limited size of powered sensors or other EPDs, the size of built-in antenna is usually small or commensurate with the wavelength. For example, smart phone's antennas are usually made as strip lines with different configurations to ensure the best possible matching with the wavelength and the impedance of input circuits. Equating these antennas to a shortening or halfwave dipoles, and expressing the value of the aperture through the wavelength can be shown
[13], that the effective aperture of the antenna is in the range from $A=0,079 \lambda^{2}$ for isotropic radiator to $0,119 \lambda^{2}$ for short and $0,13 \lambda^{2}$ for full-size half-wave dipole (the coincidence of the polarization and its maximum). Commensurating antenna's size of microminiature EPD and wavelengths of sources, it can be noted that their aperture have values that were mentioned above and its value increases with the wavelength. It's better to use longer wavelength in order to achieve maximum of efficiency. Since this is a miniature EPDs, the role of effective antennas must comply elements that are larger than the devices themselves. For instance, mounting or suspension constructions can be used as antennas. It is possible that when we install the EPD on a metal surface, the antenna itself can play the role of connection element for the metal construction, which will be a key element of energy harvesting.

In [14] microstrip antenna is proposed. The so called rectenna has a compact size due to the use of a cross shaped slot at the patch surface. Also, dual linear polarization is used in order to be able to receive arbitrarily polarized input $\mathrm{RF}$ signals. In [15] loop antenna over an AMC surface was proposed for dual-band energy harvesting. In [16] PCB-based planar dual-band monopole antenna design was provided. The simplest approach for energy harvesting is to receive the energy from the powerful and narrowband (concentrated on the frequency axis) transmitters. For instance, TV broadcasting transmitters or base stations of cellular networks can be used.

Transmitters of the base stations spread out across the city or town, and EIRP in some directions can be up to tens of watts. Implementation of the wide or ultra-wide band receivers seems to be a problem because the need of effective implementation of broadband antennas and their matching with the input circuits are compulsory. Also, we need to take into account that electromagnetic environment is unpredictable in different locations, so it would be useful to analyze the power levels using the cognitive approach to choose a frequency band. Some SDR principles can be used to select ones.

\section{Antenna Matching and Voltage Transformation}

In case of narrowband receivers, matching LC circuits can be used to achieve optimal matching of the antenna to the input of EPD and the transformation of the received power to the desired voltage (Fig.2). 


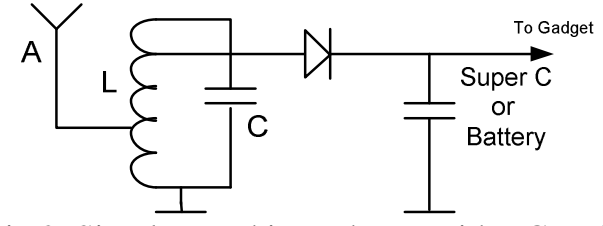

Fig.2. Simple matching scheme with LC tank.

The diode shown in the scheme illustrates the need for rectification of high-frequency oscillations into DC current. In practice, the use of semiconductor diodes is ineffective because of the "knee" of the current-voltage characteristic, which excludes the work of the diode at voltages within the "knee". Normally, mixers are used as rectifiers with in-phase signals on both inputs - so-called squaring circuit does not have "knee". However, this method is unpractical because of the need to use huge analog components. For example, in [17], authors proposed to use the dynamic threshold voltage metal oxide transistor (DTMOS) for rectifier implementation.

It is more convenient to use a chip designed for these purposes. It uses current stabilization and principle of impulse conversion. For instance, IC BQ25570 - Nano Power Boost Charger and Buck Converter for Energy Harvester Powered Applications, Texas Instruments.

The BQ25570 device is specifically designed to efficiently extract microwatts $(\mu \mathrm{W})$ to milliwatts $(\mathrm{mW})$ of power generated from a variety of high output impedance DC sources. The battery management features ensure that a rechargeable battery is not overcharged by this extracted power, with voltage boosted, or depleted beyond safe limits by a system load. In addition to the highly efficient boosting charger, the bq25570 integrates a highly efficient, nano-power buck converter for providing a second power rail to systems such as wireless sensor networks (WSN) which have stringent power and operational demands. All the capabilities of bq25570 are packed into a small foot-print 20-lead 3.5-mm x 3.5-mm QFN package (RGR). Full operating quiescent current is $488 \mathrm{nA}$. [18]

\section{Storage device.}

It is obvious that, using energy harvesting, devices can be powered directly or batteries can be charged from the energy of electromagnetic ways. This method is acceptable as the life time extension for chemical elements. However, sooner or later, we will have to change the battery. Therefore, as the energy storage elements it is preferable to use popular nowadays supercapacitors [19]. Super- or ultracapacitors, also known as high-capacity electrochemical capacitors store energy electrostatically by polarizing an electrolyte. High-capacity or supercapacitors can be charged and discharged thousands of times due to the high reversibility of the power storage mechanism. Their advantages over chemical batteries are:

- Cell voltage determined by the circuit application, not limited by the cell chemistry;

- Very high cell voltages possible (but there is a trade-off with capacity);

- High power available;

- High power density;

- Simple charging methods. No special charging or voltage detection circuits required;

- Very fast charge and discharge. Can be charged and discharged in seconds. Much faster than batteries;

- Cannot be overcharged;

- Long cycle life of more than 500,000 cycles at 100\% DOD;

- Long calendar life 10 to 20 years;

- Low impedance

The cost of modern supercapacitors is about $\$$ 0.01 per 1 Faraday, and the power density of 3216 $\mathrm{W} / \mathrm{kg}$.

In [20] authors proposed supecapacitors for energy harvesting. Printable supercapacitors were demonstrated in this article as energy storage devices in a harvester circuit using a printed RF antenna and rectifier. Authors received following results: the two series-connected supercapacitors can be charged to $1.8 \mathrm{~V}$ in a time ranging from 10 minutes to over two hours, depending on the supercapacitor size and antenna distance. The output from the voltage regulator was found to stay constant at $1.2 \mathrm{~V}$ for up to 5 or 10 hours, depending on supercapacitor size. Also, we can take a look at commercial capacitor - LS Mtron LSUC 002R8S 0120F EA.

Table 1. LS Mtron LSUC 002R8S 0120F EA parameters.

\begin{tabular}{|l|l|}
\hline Parameters & Values \\
\hline Rated Voltage & $2.8 \mathrm{~V}$ \\
\hline Capacitance & $120 \mathrm{~F}$ \\
\hline Cell configuration & Radial Cell \\
\hline Operating Temperature & $-40-65^{\circ} \mathrm{C}$ \\
\hline Resistance & $9 \mathrm{~m} \Omega$ \\
\hline Maximum Current & $74 \mathrm{~A}$ \\
\hline Leakage Current & $<0.3 \mathrm{~mA}$ \\
\hline Maximum Stored Energy & $0.11 \mathrm{~W} / \mathrm{h}$ \\
\hline Length & $46 \mathrm{~mm}$ \\
\hline Diameter & $23 \mathrm{~mm}$ \\
\hline Weight & $23 \mathrm{~g}$ \\
\hline
\end{tabular}

As we can see from these examples, the parameters of small-sized supercapacitors made 
them the ideal energy storage elements for powering small electronic devices in the application which are using Energy Harvesting.

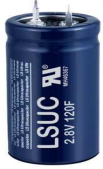

Fig.3. Supercapacitor - LS Mtron LSUC 002R8S0120FEA.

\section{Energy Consumption.}

We mentioned before that the use of energy harvesting is justified when it receives enough energy to power or charge the device. It means that the total power consumption should be less than the harvested energy. This power consumption can be divided into following elements:

- Consumption of EPD's hardware (processor, receiver, etc.) during stand-by mode;

- Consumption of EPD's transmitter, which depends on protocols and signals that are used;

Let's briefly take a look at the ways of the power save. There are many low consumption integrated circuits on the market with very small voltage and current. For example, Texas Instruments temperature sensor TMP103 consumes only 1.5 $\mu \mathrm{A} @ 1.4 \mathrm{~V}$. In the article [21] discussed some of techniques to minimize circuit consumption. These techniques are divided into two ways:

- Architectural Power Reduction Techniques: At the RTL level, one can take several steps to reduce the overall power consumption of the device. Typically, RTL based techniques minimize the dynamic power consumption of the device, however, using techniques like power gating, one can also reduce leakage power of a part of chip.

- Process Based Power Reduction Techniques: There are a lot of components of power consumption and not all can be targeted using Architectural Techniques alone. Power consumption due to effects like Drain Induced Barrier Lowering, Gate Induced Drain Leakage, sub-threshold leakage, etc. can be controlled most effectively using process based techniques.

However, some of these solutions come at the expense of performance, reliability, chip area, or several of these. Eventually, one has to reach a compromise between power, performance, and cost.

There is an example of works that were done in laboratory of IBM [22]. Authors introduced the results: "First IBM Leapfrogged Intel to $7 \mathrm{~nm}$, now it's cut power -- by using a 0.3 supply voltage -while simultaneously increasing speed at advanced nodes by boosting supply voltage during operations. Dynamic - and interconnect-boosting harnesses what is ordinarily an adversary to speed-capacitive coupling--to momentarily boost supply voltage during operations for up to three-times faster access to SRAM with a 200 picosecond clock pulse width resulting in only a minuscule increase in power, according to IBM scientist Rajiv Joshi and colleagues at the Watson Research Center in Yorktown, Heights, New York." As we can see there is an effective way to reduce the power consumption of device's hardware in standby mode.

\section{Energy-efficient communication protocols.}

Let's now consider a question about the effectiveness of the protocols that are used to exchange information among EPDs in the network. The main idea is to minimize the amount of time which is needed for transmission and as a result to minimize the power consumption of EPD. The transmission time depends on a bandwidth as well as on the amount of information, which need to be transmitted over the WSN. On the other hand, network architecture determines the length of communications radio links, necessary value of EIRP and the need of multi-hop forwarding (AdHoc, MANET). These problems were widely discussed in recent articles.

\section{Types of signals that are used in EPD}

Types of the signals have a great influence on the power consumption of EPD. These signals depend on the data rate, error probability and frequency band. All these parameters are interrelated, but, in general, the power consumption determines by the total duration of the transmission. Information is usually transmitted as packets, and the number and length of the packet define the power consumption of EPD.

\section{Impulse Radio Ultra Wide Band}

Reducing the total duration of the transmission can be achieved by using the discrete signals, namely, IR-UWB signals. It can significantly reduce the consumption of EPD by scaling down the number and duration of the pulses that are used for the packet transmission. Common Average Duty Cycle Transmission of the EPD will be the parameter representing energy savings of the device. Increasing Duty Cycle usually achieved by reducing the number of pulses per bit and its duration. In classical receivers that are based on energy integration, it means deterioration of the signal-to-noise ratio and thus increases a number of errors. As a solution, authors propose to use "non-energy" method of receiving [23]. Using this approach instead of accumulation the energy of very low-energy pulses, we use them only as a marker in time domain. Further, based on these markers may, equivalent (regenerated) pulses can 
be processed in terms of digital processing (amplitude, duration). This method and its implementation patented in Ukraine [24].

Increasing the amount of information in a limited number of pulses can be performed if each pulse will be modulated by several parameters amplitude, duration and polarity. The combination of these parameters $K$ can transmit each pulse $I=\log K$ bits of information, and the total number of bits for $n$ pulses per bit will be a traditional $I_{m}=n \log K$.

\section{Conclusion}

In the paper we discussed some problems of harvesting electromagnetic energy of transmitters from the surrounding space for power supply of micro miniature devices - sensors, controllers, etc. We proposed and evaluated techniques for "catching" electromagnetic energy, converting it into a DC current, and its accumulation in supercapacitors. On the other hand, we took into account the problem of hardware's power consumption as well as data transmission protocols and signals. Authors proposed to use IR-UWB signals that provide the best cost-effectiveness in the sense of transmitted energy.

\section{References}

1. GSMA Mobile Economy 2015 (2015) Retrieved http://www.gsmamobileeconomy.com/GSMA_Global_ Mobile_Economy_Report_2015.pdf

2. Arash Asadi, Qing Wang, Vincenzo Mancuso, A Survey on Device-to-Device Communication in Cellular Networks // IEEE COMMUNICATION SURVEYS \& TUTORIALS, VOL. 16, NO. 4, FOURTH QUARTER 2014

3. S. M. Riazul Islam, Daehan Kwak, MD. Humaun Kabir , Mahmud Hossain , Kyung-Sup Kwak The Internet of Things for Health Care: A Comprehensive Survey // IEEE Access, Vol. 3, 2015

4. Frost Gorder, P. Sizing up smart dust // IEEE Computing in Science \& Engineering, Volume:5, Issue: 6,2003

5. 5.Warneke, B. ; Last, M. ; Liebowitz, B. ; Pister, K.S.J. Smart Dust: communicating with a cubicmillimeter computer // IEEE Computer Vol. 34, Issue: 1,2001

6. The future as told through The garden and The Streets, Scenarious for the hyperconnected Nordic societies of 2015-2040., Retrieved from http://nakedapproach.fi/

\section{Chalasani,}

S.; Conrad,

J.M. A survey of energy harvesting sources for embedded sys tems // IEEE Southeastcon, 2008

8. Sudevalayam, S.; Kulkarni, P. Energy Harvesting Sensor Nodes: Survey and Implications // IEEE Communications Surveys \& Tutorials, Vol. 13, Issue: 3,2011

9. Valenta, C.R.; Durgin, G.D. Harvesting Wireless Power: Survey of Energy-Harvester Conversion Efficiency in Far-Field, Wireless Power
Transfer Systems // IEEE Microwave Magazine, Vol. 15, Issue: 4, 2014

10. Folea, S.; Ghercioiu, M. Ultra-low power WiFi tag for wireless sensing // IEEE International Conference on Automation, Quality and Testing, Robotics AQTR 2008, Vol. 3, 2008

11. Tsung-Heng Tsai; Bo-Yu Shiu; Bo-Han Song A Self-Sustaining Integrated CMOS Regulator for Solar and HF RFID Energy Harvesting Systems // IEEE Journal on Emerging and Selected Topics in Power Electronics, Vol. 2, Issue: 3, 2014

12. Iannello, F.; Simeone, O.; Spagnolini, U. Energy Management Policies for Passive RFID Sensors with RF-Energy Harvesting // IEEE International Conference on Communications (ICC), 2010

13. John D. Kraus. Antennas. // McGraw-Hill Book Company. New York, Toronto, London. 1950

14. G.P.Ramesh, A.Rajan Microstrip Antenna Designs for RF Energy Harvesting // International Conference on Communication and Signal Processing, 2014, India

15. Hirokazu Kamoda, Shoichi Kitazawa, Naoya Kukutsu, Kiyoshi Kobayashi Loop Antenna Over Artificial Magnetic Conductor Surface and Its Application to Dual-Band RF Energy Harvesting // IEEE TRANSACTIONS ON ANTENNAS AND PROPAGATION, VOL. 63, NO. 10, OCTOBER 2015

16. Xi Shao; Bo Li; Shahshahan, N.; Goldsman, N.; Salter, T.S.; Metze, G.M. A planar dual-band antenna design for RF energy harvesting applications // International Semiconductor Device Research Symposium (ISDRS), 2011

17. Chouhan, S.S.; Halonen, K. The design and implementation of DTMOS biased all PMOS rectifier for RF energy harvesting // IEEE 12th International New Circuits and Systems Conference (NEWCAS), 2014

18. Texas Instruments, Nano Power Boost Charger and Buck Converter for Energy Harvester Powered Applications BQ25570, REVISED MARCH 2015

19. Mars, P. A survey of supercapacitors, their applications, power design with supercapacitors, and future directions // IEEE Technology Time Machine Symposium on Technologies Beyond 2020 (TTM), 2011

20. Miao Lia, Jarno Salomaa, Antti Kalanti, Sampo Tuukkanen, Petri Heljo, Kari Halonen A printable supercapacitor as a storage unit in an RF energy harvester // INTERNATIONAL JOURNAL OF ELECTRICAL POWER \& ENERGY SYSTEMS VOL. 58, JUNE 2014

21. S. Maheshwari , N. Srivastava \& R. Ranjan "Low-power design techniques" // September 24, 2015

22. R. Colin Johnson Lowers Voltage to $0.3 \mathrm{v}$ in Prep for $7 \mathrm{~nm} / /$ Retrieved from http://www.eetimes.com/document.asp?doc_id=1327186

23. S. Bunin, Non energetic IR-UWB receiver and its Noise immunity // 21th International Crimean Conference: Microwave and Telecommunication Technology (CriMiCo), 2011

24. The Method of Short Impulse Radio Signals Reception and its Implementation. Patent of Ukraine \#97705, March 12, 2012

Received in final form on April 26, 2016 


\section{Бунін С.Г., Р.Ю. Жогов}

Певні ідеї щодо збору електромагнітної енергії вільних коливань

Проблематика. Збір електромагнітної енергії вільних коливань $є$ актуальною темою. Система для збору електромагнітної енергії має багато складових елементів, що робить проектування цих пристроїв комплексною проблемою.

Мета досліджень. Оптимальні способи збору та акумуляції енергії електромагнітних коливань.

Методика реалізації. Аналіз всіх відомих публікацій, присвячених збору та акумуляції електромагнітної енергії вільних коливань, а також виявлення певних оптимальних елементів для систем збору.

Результати досліджень. По кожному з складових елементів системи збору енергії електромагнітних коливань (антени, детектори, узгоджувальні кола та ін.) представлені оптимальні рішення, а також певні практичні рекомендації щодо реалізації. Також запропоновані над широкосмугові імпульсні сигнали, які можуть бути використані для більш енергетично ефективних комунікацій.

Висновки. Збір електромагнітної енергії може бути ефективно застосованих для живлення певних пристроїв (наприклад, сенсори). Також з метою ефективного використання енергії, надширокосмугові сигнали можуть бути застосовані в цих приладах.

Ключові слова: збір електромагнітної енергії, надширокосмугові сигнали, сенсори, суперконденсатори.

Бунин С.Г., Жогов Р. Ю.

Некоторые идеи по поводу сбора энергии свободных электромагнитных колебаний

Проблематика. Сбор энергии свободных электромагнитных колебаний является актуальной темой. Система для сбора электромагнитной энергии состоит из большого числа элементов, что делает проектирование данных устройств комплексной задачей.

Цель исследований. Оптимальные способы сбора и аккумуляции энергии электромагнитных колебаний.

Методика реализации. Анализ всех известных публикаций, посвященных теме сбора электромагнитной энергии, а так же выявление оптимальных составных элементов для систем сбора.

Результаты исследований. По каждому из элементов системы сбора электромагнитной энергии (антенны, детекторы, согласующие цепи и др.) представлены оптимальные решения, а так же некоторые практические рекомендации относительно реализации. Так же предложено использование сверширокополосных импульсных сигналов для более энергоэффективных комуникаций.

Выводы. Сбор электромагнитной энергии может быть эффективно применен для питания определенных устройств (например, сенсоры). Так же с целью эффективного использования энергии, сверширокополосные сигналы могут быть использованы в данных устройствах.

Ключевые слова: сбор электромагнитной энергии; сверхширокополосные сигналы; сенсоры; суперконденсаторы. 